Journal of Solid State Chemistry 151, 308\}312 (2000)

https://doi.org/10.1006/jssc.2000.8659

\title{
Synthesis and crystal structures of $\mathrm{Cd}(\mathrm{OH}) \mathrm{Cl}$ and $\mathrm{Cu}(\mathrm{OH}) \mathrm{Cl}$ and relationship to brucite type
}

\author{
Y. Cudennec, A. Riou* , Y. Gérault and A. Lecerf
}

Groupe de Recherche en Chimie et Métallurgie, Institut National des Sciences Appliquées de Rennes, 20 Avenue des buttes de Coesmes, 35043 Rennes Cédex, France.

* Laboratoire IMMO Faculté des Sciences, Université d'Angers, 2 Boulevard Lavoisier, 49045 Angers Cedex, France. 


\begin{abstract}
Synthesis of single crystals of $\mathrm{Cd}(\mathrm{OH}) \mathrm{Cl}$ and $\mathrm{Cu}(\mathrm{OH}) \mathrm{Cl}$ allowed to revisit the structure of these hydroxychlorides and confirm their space group: $\mathrm{P} 6_{3} \mathrm{mc}\left(\mathrm{R}=0.041 ; \mathrm{R}_{\mathrm{w}}=0.050\right)$ for $\mathrm{Cd}(\mathrm{OH}) \mathrm{Cl}$ and $\mathrm{P} 2{ }_{1} / \mathrm{c}\left(\mathrm{R}=0.051 ; \mathrm{R}_{\mathrm{w}}=0.072\right)$ for $\mathrm{Cu}(\mathrm{OH}) \mathrm{Cl}$. Positions of hydrogen atoms were determined and an hypothesis of hydrogen bonds is discussed in relation with the infrared spectra. A comparison of the structures shows that an isomorphism is not possible between the two compounds, due to the important Jahn-Teller effect of divalent copper. On the other hand, a structural relationship exists between $\mathrm{Cd}(\mathrm{OH}) \mathrm{Cl}$ and $\beta-\mathrm{Cd}(\mathrm{OH})_{2}$ which belongs to the brucite type family.
\end{abstract}

\title{
Key words
}

Crystal structure, cadmium, copper, hydroxychloride. 


\section{INTRODUCTION}

Many studies have been published on divalent metal hydroxychlorides, $\mathrm{M}(\mathrm{OH}) \mathrm{Cl}$, which structures are related to the brucite type (1-5). To our knowledge, few structural studies were carried out on single crystals, excepted for $\mathrm{Cd}(\mathrm{OH}) \mathrm{Cl}$ but the crystal structure was determined in 1934 (6) and for $\mathrm{Cu}(\mathrm{OH}) \mathrm{Cl}$, which a more recent determination gives a $\mathrm{R}$ value near $13 \%$ (7).

In a recent publication (5), we exposed a new route for the preparation of cadmium hydroxychlorides, based on using more reactive starting material: $\gamma-\mathrm{Cd}(\mathrm{OH})_{2}$. Single crystals of $\beta-\mathrm{Cd}_{2}(\mathrm{OH})_{3} \mathrm{Cl}$ and $\mathrm{Cd}(\mathrm{OH}) \mathrm{Cl}$ were obtained in this way. The crystal structure determination of the first one shows that it is isostructural with atacamite, the corresponding solid phase of copper, $\mathrm{Cu}_{2}(\mathrm{OH})_{3} \mathrm{Cl}$. This was a surprising result, by reason of the peculiar surrounding of copper, due to Jahn-Teller effect.

The aims of this paper are to propose recent data for structural studies of $\mathrm{Cd}(\mathrm{OH}) \mathrm{Cl}$ and $\mathrm{Cu}(\mathrm{OH}) \mathrm{Cl}$, confirm their space groups, try to show a relationship to the brucite type and to explain why the isomorphism between copper and cadmium compounds is possible only in the case of $\mathrm{M}_{2}(\mathrm{OH})_{3} \mathrm{Cl}$ and not for $\mathrm{M}(\mathrm{OH}) \mathrm{Cl}$.

\section{SYNTHESIS AND CRYSTAL STRUCTURE DETERMINATION}

Crystals of $\mathrm{Cd}(\mathrm{OH}) \mathrm{Cl}$ were synthesized under hydrothermal conditions (5). A reacting system containing 0.1 mole of $\mathrm{CdCl}_{2}, 2.5 \mathrm{H}_{2} \mathrm{O}, 0.1$ mole of $\gamma-\mathrm{Cd}(\mathrm{OH})_{2}$ and 100 moles of $\mathrm{H}_{2} \mathrm{O}$ is gradually heated from room temperature to $323 \mathrm{~K}$, during four weeks. In the presence of $\mathrm{Cl}^{-}$ ions, crystals of $\gamma-\mathrm{Cd}(\mathrm{OH})_{2}$ are slowly transformed into $\mathrm{Cd}(\mathrm{OH}) \mathrm{Cl}$ according to the following scheme:

$$
\mathrm{Cd}_{(\text {aq })}^{2+}+2 \mathrm{Cl}_{(\mathrm{aq})}^{-}+\gamma-\mathrm{Cd}(\mathrm{OH})_{2(\mathrm{~s})} \quad \longrightarrow \quad 2 \mathrm{Cd}(\mathrm{OH}) \mathrm{Cl}_{(\mathrm{s})}
$$


Owing to the large grain size of the starting material $\gamma-\mathrm{Cd}(\mathrm{OH})_{2}$ (around several tenths of a $\mathrm{mm}$ ), the reaction kinetic is very slow and favors the formation of large crystals. Crystals of $\mathrm{Cd}(\mathrm{OH}) \mathrm{Cl}$ are colorless and have an hexagonal prismatic shape.

Crystals of $\mathrm{Cu}(\mathrm{OH}) \mathrm{Cl}$ were prepared according to the method used by liataka and al.(7). They appear under the shape of small olive-green plates.

Intensity data collections were performed with a MACH 3 NONIUS diffractometer operating with the Mo-K $\alpha$ radiation. The lattice parameters were refined by least squares from 25 reflections. The structural determination, using the XTAL and MOLEN package, confirmed the space groups, $\mathrm{P} 6{ }_{3} \mathrm{mc}$ for $\mathrm{Cd}(\mathrm{OH}) \mathrm{Cl}(6)$ and $\mathrm{P} 2_{1} / \mathrm{c}$ for $\mathrm{Cu}(\mathrm{OH}) \mathrm{Cl}(1)$. Lorentz-polarisation and absorption corrections have been applied to the data.

TABLE I

Single crystal $\mathrm{X}$-ray data and structure refinement results

\begin{tabular}{|c|c|c|}
\hline Crystal data & $\mathrm{Cd}(\mathrm{OH}) \mathrm{Cl}$ & $\mathrm{Cu}(\mathrm{OH}) \mathrm{Cl}$ \\
\hline Crystal dimensions ( $\mathrm{mm}$ ) & $0.15 \times 0.15 \times 0.3$ & $0.1 \times 0.25 \times 0.35$ \\
\hline Crystal system & Hexagonal & Monoclinic \\
\hline Space group & $\mathrm{P} 6_{3} \mathrm{mc}$ & $\mathrm{P} 2{ }_{1} / \mathrm{c}$ \\
\hline $\mathrm{a}(\mathrm{nm})$ & $0.36648(5)$ & $0.62953(4)$ \\
\hline $\mathrm{b}(\mathrm{nm})$ & $0.36648(5)$ & $0.66649(11)$ \\
\hline $\mathrm{c}(\mathrm{nm})$ & $1.02305(11)$ & $0.55580(4)$ \\
\hline$\gamma$ or $\beta$ (degrees) & 120 & $118.138(11)$ \\
\hline$Z$ & 2 & 4 \\
\hline Density calc. $\left(\right.$ g.cm $\left.{ }^{-3}\right)$ & 4.592 & 3.762 \\
\hline$\theta\left(^{\circ}\right)(\min ., \max )$. & 2,30 & 2,30 \\
\hline$h k l$ (min., max. ) & $h(0,2) k(0,4) l(0,14)$ & $h(-10,8) k(0,10) l(0,8)$ \\
\hline$\mu(\mathrm{Mo}-\mathrm{K} \alpha)\left(\mathrm{cm}^{-1}\right)$ & 98.8 & 115.7 \\
\hline Transmission factors & 0.699 to 1.478 & 0.733 to 1.536 \\
\hline Total measured reflections & 225 & 1040 \\
\hline Unique reflections & 87 & 889 \\
\hline Reflections: $\mathrm{I}>3 \sigma(\mathrm{I})$ & 84 & 799 \\
\hline Variable parameters & 10 & 28 \\
\hline $\mathrm{R}, \mathrm{Rw}$ & $0.041,0.050$ & $0.051,0.072$ \\
\hline G.O.F. & 1.918 & 1.925 \\
\hline
\end{tabular}

The structure of the two compounds is composed of one independent atom of $\mathrm{M}^{2+}$, chloride, oxygen and hydrogen. The non-hydrogen atoms were refined anisotropically. Hydrogen 
atoms were included but atomic parameters were not refined. Details on X-ray data collection and results of structure refinements are given in Table 1 and atomic coordinates with displacement parameters, in Table 2.

TABLE II

Atomic coordinates and displacement parameters

\begin{tabular}{cllll|}
\hline Atom & \multicolumn{1}{c}{$\mathrm{x}$} & \multicolumn{1}{c}{$\mathrm{y}$} & \multicolumn{1}{c}{$\mathrm{z}$} & \multicolumn{1}{c}{ Ueq x 100 } \\
\multicolumn{5}{c}{$\mathrm{Cd}(\mathrm{OH}) \mathrm{Cl}$} \\
$\mathrm{T}$ & & \\
$\mathrm{Cd}$ & $1 / 3$ & $2 / 3$ & 0.00791 & $1.59(4)$ \\
$\mathrm{Cl}$ & $1 / 3$ & $2 / 3$ & $0.3433(5)$ & $1.7(2)$ \\
$\mathrm{O}$ & 0.0 & 0.0 & $0.0892(14)$ & $1.9(6)$ \\
$\mathrm{H}^{*}$ & 0.0 & 0.0 & 0.180 & 3.5 \\
& & $\mathrm{Cu}(\mathrm{OH}) \mathrm{Cl}$ & & \\
& & & & \\
$\mathrm{Cu}$ & $0.03201(7)$ & $0.11772(6)$ & $0.28577(7)$ & $0.98(2)$ \\
$\mathrm{Cl}$ & $0.3115(1)$ & $0.0907(1)$ & $0.1334(2)$ & $1.03(3)$ \\
$\mathrm{O}$ & $0.8807(4)$ & $0.1478(3)$ & $0.5318(5)$ & $0.71(7)$ \\
$\mathrm{H}^{*}$ & 0.700 & 0.165 & 0.420 & 3.5 \\
& & & &
\end{tabular}

$H^{*}$ atom coordinates were not refined.

$\begin{array}{lllllll}\text { Atoms } & \mathrm{U}(1,1) & \mathrm{U}(2,2) & \mathrm{U}(3,3) & \mathrm{U}(1,2) & \mathrm{U}(1,3) & \mathrm{U}(2,3) \\ & & & \mathrm{Cd}(\mathrm{OH}) \mathrm{Cl} & & & \\ \mathrm{Cd} & 1.49(3) & 1.49(3) & 1.80(5) & 0.75 & 0.0 & 0.0 \\ \mathrm{Cl} & 2.05(14) & 2.05(14) & 0.9(2) & 1.03 & 0.0 & 0.0 \\ \mathrm{O} & 2.8(5) & 2.8(5) & 0.1(6) & 1.39 & 0.0 & 0.0 \\ & & & & & & \\ \mathrm{Cu} & 1.16(1) & 0.82(2) & 0.95(1) & 0.191(9) & 0.60(1) & 0.225(9) \\ \mathrm{Cl} & 0.66(2) & 1.45(3) & 0.99(2) & 0.03(2) & 0.22(2) & 0.00(2) \\ \mathrm{O} & 0.45(6) & 0.92(8) & 0.75(7) & 0.04(6) & 0.02(5) & 0.09(6)\end{array}$

General displacement anisotropic parameters : $U_{(i, j)} \times 100$ 


\section{Structural comparison and relationship to the brucite type}

The two structures display parallel sheets of $\mathrm{M}(\mathrm{OH}) \mathrm{Cl}$ formula, which could be only linked together by hydrogen bonds. The cadmium ion is surrounded by 3 oxygen atoms at $0.2273 \mathrm{~nm}$ and 3 chloride atoms at $0.2704 \mathrm{~nm}$. Oxygen atoms are situated in cis-positions in the same half-space defined by cadmium atoms belonging to the sheet, all chloride atoms being located in the other half-space.

TABLE III

Interatomic bond distances and angles

\section{$\mathrm{Cd} \mathrm{O}_{3} \mathrm{Cl}_{3}$ Polyhedron}

$\underline{\text { Bond lengths (nm) }}$

(x3) $\mathrm{Cd}-\mathrm{O}: 0.2273(5)$

(x3) $\mathrm{Cd}-\mathrm{Cl}: 0.2704(3)$ (x3) $\mathrm{O}-\mathrm{Cd}-\mathrm{O}^{\prime}:$ : 107.4(3)

(x3) $\mathrm{O}-\mathrm{Cd}-\mathrm{Cl}: 162.9$ (4)

(x6) $\mathrm{O}-\mathrm{Cd}-\mathrm{Cl}^{\prime}:$ : 82.2(3)

(x3) $\mathrm{Cl}-\mathrm{Cd}-\mathrm{Cl}^{\prime}:$ 85.32(8)
Hydrogen bond hypothesis

(bonds: $\mathrm{nm}$ and angles $\left({ }^{\circ}\right)$

$\mathrm{Cu} \mathrm{O}_{3} \mathrm{Cl}_{3}$ Polyhedron

Bond lengths (nm)

$$
\begin{aligned}
& \mathrm{Cu}-\mathrm{O}: 0.1984(3) \\
& \mathrm{Cu}-\mathrm{O}^{\prime}: 0.2012(4) \\
& \mathrm{Cu}-\mathrm{O}^{\prime \prime}: 0.2018(3) \\
& \mathrm{Cu}-\mathrm{Cl}: 0.22915(11) \\
& \mathrm{Cu}-\mathrm{Cl}^{\prime}: 0.26985(8) \\
& \mathrm{Cu}-\mathrm{Cl}^{\prime \prime}: 0.27201(8)
\end{aligned}
$$

\section{Angles ( $\left.{ }^{\circ}\right)$}

$\mathrm{O}-\mathrm{Cu}-\mathrm{O}^{\prime}: \quad 81.22(11)$

$\mathrm{O}-\mathrm{Cu}-\mathrm{O}^{\prime \prime}:$ 166.82(8)

$\mathrm{O}-\mathrm{Cu}-\mathrm{Cl}: 92.46(9)$

$\mathrm{O}-\mathrm{Cu}-\mathrm{Cl}^{\prime}$ : $84.15(6)$

$\mathrm{O}-\mathrm{Cu}-\mathrm{Cl}^{\prime \prime}: 110.11(6)$

$\mathrm{O}^{\prime}-\mathrm{Cu}-\mathrm{O}^{\prime \prime}: 100.35(11)$

$\mathrm{O}^{\prime}-\mathrm{Cu}-\mathrm{Cl}: 162.07(6)$

$\mathrm{O}^{\prime}-\mathrm{Cu}-\mathrm{Cl}^{\prime}:$ 101.22(6)

$\mathrm{O}^{\prime}-\mathrm{Cu}-\mathrm{Cl}^{\prime \prime}:$ 78.52(6)

$\mathrm{O}^{\prime \prime}-\mathrm{Cu}-\mathrm{Cl}:$ 89.64(9)

$\mathrm{O}^{\prime \prime}-\mathrm{Cu}-\mathrm{Cl}^{\prime}: \quad 82.71(6)$

$\mathrm{O}^{\prime \prime}-\mathrm{Cu}-\mathrm{Cl}^{\prime \prime}: \quad 82.96(6)$

$\mathrm{Cl}-\mathrm{Cu}-\mathrm{Cl}^{\prime}:$ : $94.75(3)$

$\mathrm{Cl}-\mathrm{Cu}-\mathrm{Cl}^{\prime \prime}: \quad 88.08(3)$

$\mathrm{Cl}^{\prime}-\mathrm{Cu}-\mathrm{Cl}^{\prime \prime}:$ 165.37(3)
$\mathrm{O}-\mathrm{H}: 0.093$

(x3) $\mathrm{O} \ldots . . . . \mathrm{Cl}: 0.3352(12)$

(x3) $\mathrm{H}$........ 0.270

(x3) $\mathrm{O}-\mathrm{H}$........Cl : 128.3

(x3) $\mathrm{Cd}-\mathrm{O}-\mathrm{H}: 111.5$
Hydrogen bond hypothesis

(bonds: $\mathrm{nm}$ and angles $\left({ }^{\circ}\right)$

$\mathrm{O}-\mathrm{H}: 0.101$

$\mathrm{O}$........Cl : 0.3226(3)

$\mathrm{H}$....... Cl : 0.226

$\mathrm{O}-\mathrm{H}$....... Cl : 159.7

$\mathrm{Cu}-\mathrm{O}-\mathrm{H}: 111.4$

$\mathrm{Cu}^{\prime}-\mathrm{O}-\mathrm{H}: 110.4$

$\mathrm{Cu}^{\prime \prime}-\mathrm{O}-\mathrm{H}: 112.0$

(Atoms noted (') or (") correspond to equivalent positions) 
The polyhedron $\mathrm{Cd}(\mathrm{O})_{3}(\mathrm{Cl})_{3}$ thus obtained, is very distorted as shown in Fig 1, where are drawn surroundings of $\mathrm{M}^{2+}, \mathrm{Cl}$ and $\mathrm{O}$ in $\beta-\mathrm{Cd}(\mathrm{OH})_{2}$ (1a) (brucite type), $\mathrm{Cd}(\mathrm{OH}) \mathrm{Cl}(1 \mathrm{~b})$ and $\mathrm{Cu}(\mathrm{OH}) \mathrm{Cl}(1 \mathrm{c})$. Values of interatomic distances and angles are reported in Table 3. On the other hand, the polyhedron $\mathrm{Cu}(\mathrm{O})_{3}(\mathrm{Cl})_{3}$ is very different. Two chloride atoms are located in trans-positions at a long distance of copper, 0.26985 and $0.27201 \mathrm{~nm}$ and the third one is placed at a very short distance, $0.22915 \mathrm{~nm}$ in the very distorted square-plane surrounding of copper. This unexpected short distance for $\mathrm{Cu}-\mathrm{Cl}$ bonds is naturally due to the important JahnTeller effect displayed by copper $(4+2$, here). Therefore, chloride atoms are found alternatively with oxygen atoms in each half-space defined as above (see Fig.1c and 4). JahnTeller effect is straightforwardly the reason which explains why the two compounds $\mathrm{Cd}(\mathrm{OH}) \mathrm{Cl}$ and $\mathrm{Cu}(\mathrm{OH}) \mathrm{Cl}$ cannot have isomorphous structures. In a recent publication (5), we have determined the crystal structure of $\beta-\mathrm{Cd}_{2}(\mathrm{OH})_{3} \mathrm{Cl}$ and surprisingly it was isomorphous with atacamite $\mathrm{Cu}_{2}(\mathrm{OH})_{3} \mathrm{Cl}(11)$. In contrast to the $\mathrm{M}(\mathrm{OH}) \mathrm{Cl}$ type, an isomorphism is possible between cadmium and copper in the case of $\mathrm{M}_{2}(\mathrm{OH})_{3} \mathrm{Cl}$. In fact, in the structure of $\mathrm{M}_{2}(\mathrm{OH})_{3} \mathrm{Cl}$ two types of polyhedra exist which contain one or two chloride atoms instead of three in $\mathrm{M}(\mathrm{OH}) \mathrm{Cl}$ polyhedra : $\mathrm{M}(\mathrm{O})_{5} \mathrm{Cl}$ and $\mathrm{M}(\mathrm{O})_{4}(\mathrm{Cl})_{2}$. In the structure of atacamite, chloride atoms are always placed at a long distance of copper, 0.2750 and (x2) $0.2776 \mathrm{~nm}$ (Jahn-Teller effect). These distances correspond approximately to the distances between cadmium and chloride and naturally, without Jahn-Teller effect in the case of cadmium, 0.2735 and $(\mathrm{x} 2) 0.2829 \mathrm{~nm}$. The same phenomenon can be noticed for the oxygen located at the opposite side of chloride in the polyhedron $\mathrm{M}(\mathrm{O})_{5} \mathrm{Cl} ; \mathrm{Cu}-\mathrm{O}: 0.2358 \mathrm{~nm}$ (Jahn-Teller effect); $\mathrm{Cd}-\mathrm{O}: 0.2328 \mathrm{~nm}$ (without effect). In these conditions the replacement of $\mathrm{Cu}^{2+}$ by $\mathrm{Cd}^{2+}$ ion does not lead to a great deformation of the structure. This coincidence in the values of distances $\mathrm{M}-\mathrm{Cl}$ and $\mathrm{M}-\mathrm{O}$ explains why the isomorphism between $\mathrm{Cu}_{2}(\mathrm{OH})_{3} \mathrm{Cl}$ and $\beta$ $\mathrm{Cd}_{2}(\mathrm{OH})_{3} \mathrm{Cl}$ is possible. 
If we compare the structure of $\mathrm{Cd}(\mathrm{OH}) \mathrm{Cl}$ with $\beta-\mathrm{Cd}(\mathrm{OH})_{2}$ ( space group $\mathrm{P}-3 \mathrm{~m} 1, \mathrm{a}=0.3496$ $\mathrm{nm}, \mathrm{c}=0.4702 \mathrm{~nm})$, there is an evident relationship. In brucite, $\mathrm{Cd}(\mathrm{O})_{6}$ polyhedra are regular and consequently, have the same orientation in the different sheets. So, the c parameter, perpendicular to the sheets, corresponds to the distance between 2 sheets. It is not the case for $\mathrm{Cd}(\mathrm{OH}) \mathrm{Cl}$ (space group $\mathrm{P} 6_{3} \mathrm{mc}, \mathrm{a}=0.36648 \mathrm{~nm}, \mathrm{c}=1.02305 \mathrm{~nm}$ ), which polyhedra, $\mathrm{Cd}(\mathrm{O})_{3} \mathrm{Cl}_{3}$, very distorted with the substitution of three oxygens by three chlorides, have not the same orientation in two neighboring sheets ( rotation of $180^{\circ}$ about $\mathrm{c}$ axis ), so that the $\mathrm{c}$ parameter is equal to the distance corresponding to three sheets ( see Fig.2 and 3).

\section{Hydrogen bonds hypothesis}

In brucite structural type, it was assumed, regarding the high value of the $v(\mathrm{O}-\mathrm{H})$ stretching vibration ( near $\left.3600 \mathrm{~cm}^{-1}\right)$ and the too long distance between hydrogen and acceptor $(\mathrm{H} \ldots . . \mathrm{O}>$ $0.240 \mathrm{~nm}$ ), that no hydrogen bonds could be considered. In a recent publication this result is widely discussed (8). The authors give several reasons to think, that in contrast to most of the literature published, hydrogen bonding in brucite type cannot be excluded in principle, even if the distance $\mathrm{H}$--acceptor is larger than $0.240 \mathrm{~nm}$. In this hypothesis we have studied the possibilities of such hydrogen bonding in $\beta-\mathrm{Cd}(\mathrm{OH})_{2}, \mathrm{Cd}(\mathrm{OH}) \mathrm{Cl}$ and $\mathrm{Cu}(\mathrm{OH}) \mathrm{Cl}$. In this way, IR spectra of the three compounds have been performed in Nujol, using an FTIR spectrometer (Fig.5).

The crystal structure of $\beta-\mathrm{Cd}(\mathrm{OH})_{2}$ has been determined for the first time with a single crystal in 1970 (9). Very recently the structure has been revisited and the atomic position of hydrogen atom determined (10). Distances (nm) and angles $\left(^{\circ}\right)$ of the surrounding of $\mathrm{H}$ atom, issued from this last publication are : $\mathrm{O}-\mathrm{H}: 0.089 ;(\mathrm{x} 3) \mathrm{O} \ldots . . \mathrm{O}^{\prime}$ (acceptor) : 0.324; (x3) H.....' : 0.260; (x3) Cd-O-H : 118.3; (x3) O-H....' : 129.1. As shown on Fig.1a and Fig.2, three hydrogen bonds could be possible per hydrogen atom with three different oxygen acceptors located at the same distance. Reciprocally each oxygen atom could be involved in three hydrogen bonds 
with three different hydrogen atoms. Although these bonds are very weak $(v(\mathrm{O}-\mathrm{H})=3597.4$ $\mathrm{cm}^{-1}$ ) (Fig.5a), we think they could be mainly responsible of the crystal cohesion, because they form a close network of overlapped bonds (Fig. 2).

The corresponding values of distances and angles in the surrounding of $\mathrm{H}$ atom, obtained in this work, for $\mathrm{Cd}(\mathrm{OH}) \mathrm{Cl}$ and $\mathrm{Cu}(\mathrm{OH}) \mathrm{Cl}$ are reported in Table 3. In the case of $\mathrm{Cd}(\mathrm{OH}) \mathrm{Cl}$, they are similar to those of $\beta-\mathrm{Cd}(\mathrm{OH})_{2}$; the main difference being due to an increase of the iono-covalent radii of the acceptor which is here, $\mathrm{Cl}$ atom instead of $\mathrm{O}$. The strength of hydrogen bonds seems to be a little higher, in regard of the value of $\mathrm{O}-\mathrm{H}$ stretching mode $\left(v(\mathrm{O}-\mathrm{H})=3514.7 \mathrm{~cm}^{-1}\right)($ Fig. $5 \mathrm{~b})$. Nevertheless the structure of $\mathrm{Cd}(\mathrm{OH}) \mathrm{Cl}$ is not so stable as the brucite type because hydrogen atoms are twice less numerous as in brucite and then, possibilities of hydrogen bonds also (Fig. $1 \mathrm{~b}$ and 3). As for $\mathrm{Cu}(\mathrm{OH}) \mathrm{Cl}$, its structure is more different of the brucite type than the $\mathrm{Cd}(\mathrm{OH}) \mathrm{Cl}$ one. This is due to Jahn-Teller effect. Only one hydrogen bond could exist per hydrogen atom ( See Fig.1c and 4), but the strength of this bond is straightforwardly more important $\left(\mathrm{v}(\mathrm{O}-\mathrm{H})=3395.8 \mathrm{~cm}^{-1}\right.$ and $\left.\mathrm{O} \ldots . . \mathrm{H}: 0.226 \mathrm{~nm}\right) . \mathrm{In}$ this case, existence of hydrogen bonding is absolutely certain.

Comparison of hydrogen bonding hypothesis in the three compounds shows that, if bonds are weak, they give rise to a dense network, but if bonds are less numerous they are strengthened. This fact may allow to conclude to the probability of existence of hydrogen bonds more or less important, in the three compounds and that hydrogen bonds could be mainly responsible of the structural cohesion between layers.

\section{REFERENCES}

1. H.R. Ostwald und W. Feitknetch, Helv. Chim. Acta, 44, 847 (1961).

2. L. Walter-Lévy et D.Groult, Bull. Soc. Chim. France, 11, 3868 (1970).

3. L.Walter-Lévy, A.M. Goreaud et M.Goreaud, Bull. Soc. Chim. France, 8-9, 2789 (1970). 
4. B.Weckler and H.D. Lutz, Spectrochim. Acta, A52, 1507 (1996).

5. Y.Cudennec, Y. Gérault et A. Lecerf, C.R. Acad. Sci. Paris, 324(IIb), 457 (1997).

6. J.L. Hoard and J.D. Grenko, Z. Kristallogr., 87, 110 (1934).

7. Y. Iitaka, S. Locchi and H.R. Ostwald, Helv. Chim. Acta, 44, 2095 (1961).

8. Ch.Mockenhaupt, Th.Zeiske and H.D.Lutz, J. Molec. Structure, 443, 191 (1998).

9. G.Bertrand and Y.Dusausoy, C.R. Acad. Sci. Paris, 270(C), 612 (1970).

10. L.Hemmingsen, R.Bauer, M.J.Bjerrum, K.Schwarz, P.Blaha and P.Andersen, Inorg. Chem., 38(12), 2860 (1999).

11. J.B.Parise and B.G.Hyde, Acta Cryst., C42, 1277 (1986).

The authors thank Doctor C. Paul for proofreading the English version of this publication. 

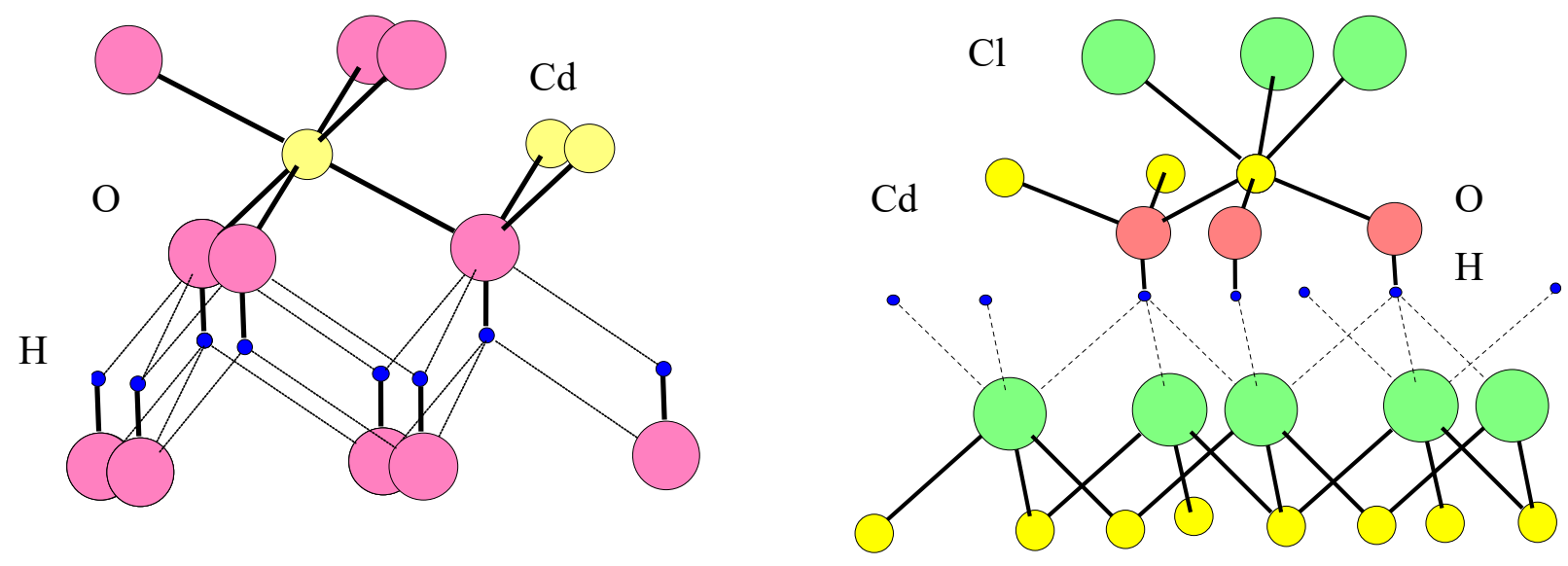

(b)

(a)

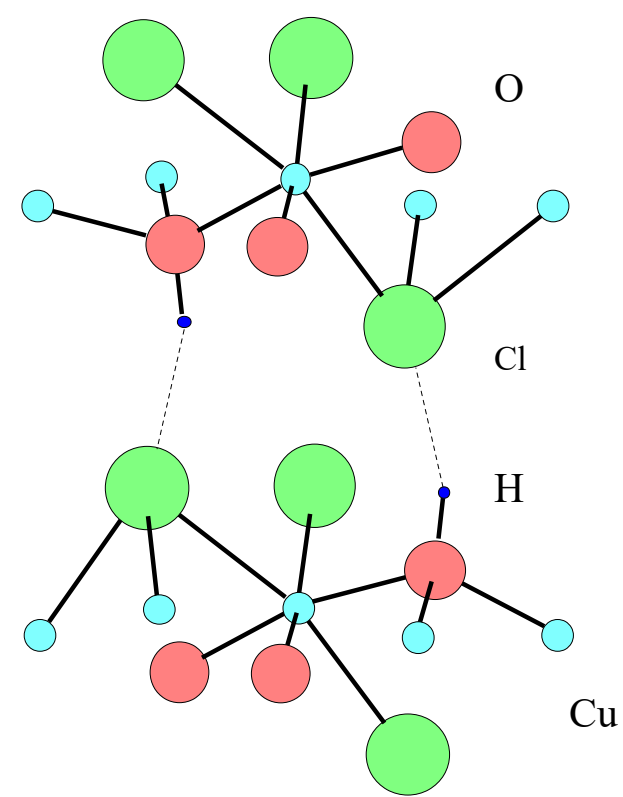

(c)

FIG. 1. Surrounding of atoms in $(a) \beta-C d(O H) 2$, (b) $\mathrm{Cd}(\mathrm{OH}) \mathrm{Cl}$, and $(\mathrm{c}) \mathrm{Cu}(\mathrm{OH}) \mathrm{Cl}$. 
FIG. 2. $\beta-\mathrm{Cd}(\mathrm{OH}) 2$ : crystal structure in perspective.

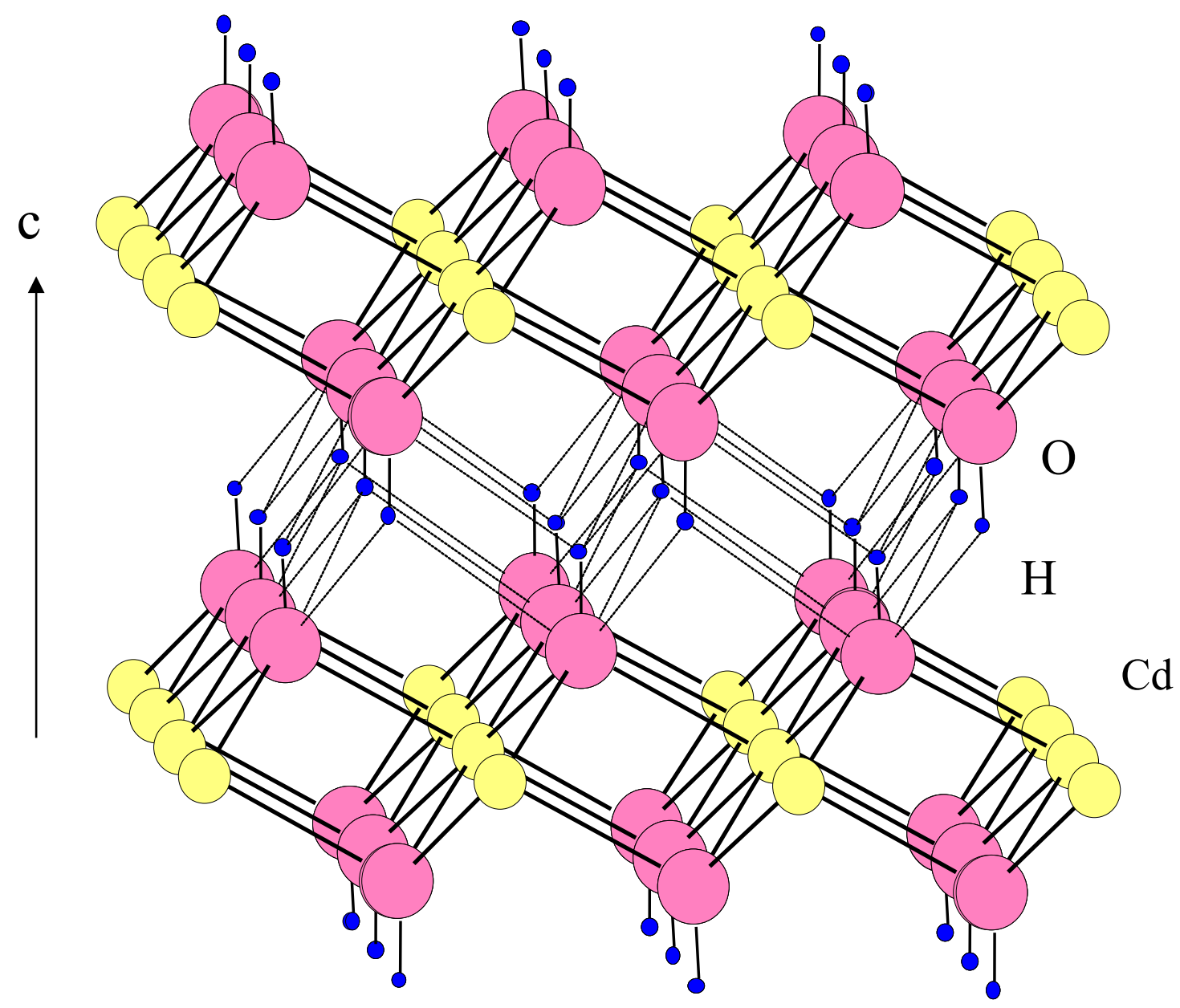


FIG. 3. $\mathrm{Cd}(\mathrm{OH}) \mathrm{Cl}$ : crystal structure in perspective

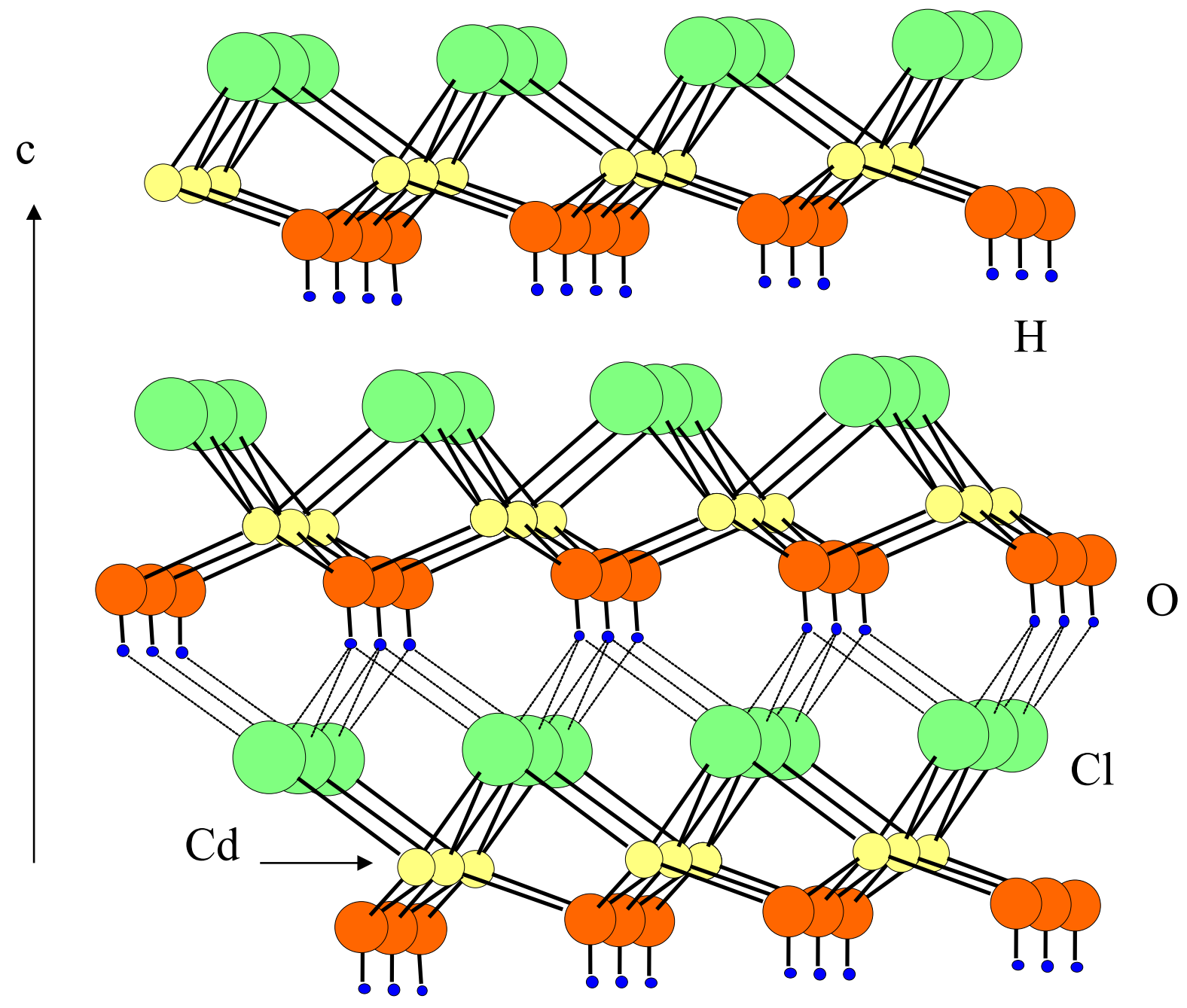


FIG. 4. $\mathrm{Cu}(\mathrm{OH}) \mathrm{Cl}$ : crystal structure in perspective

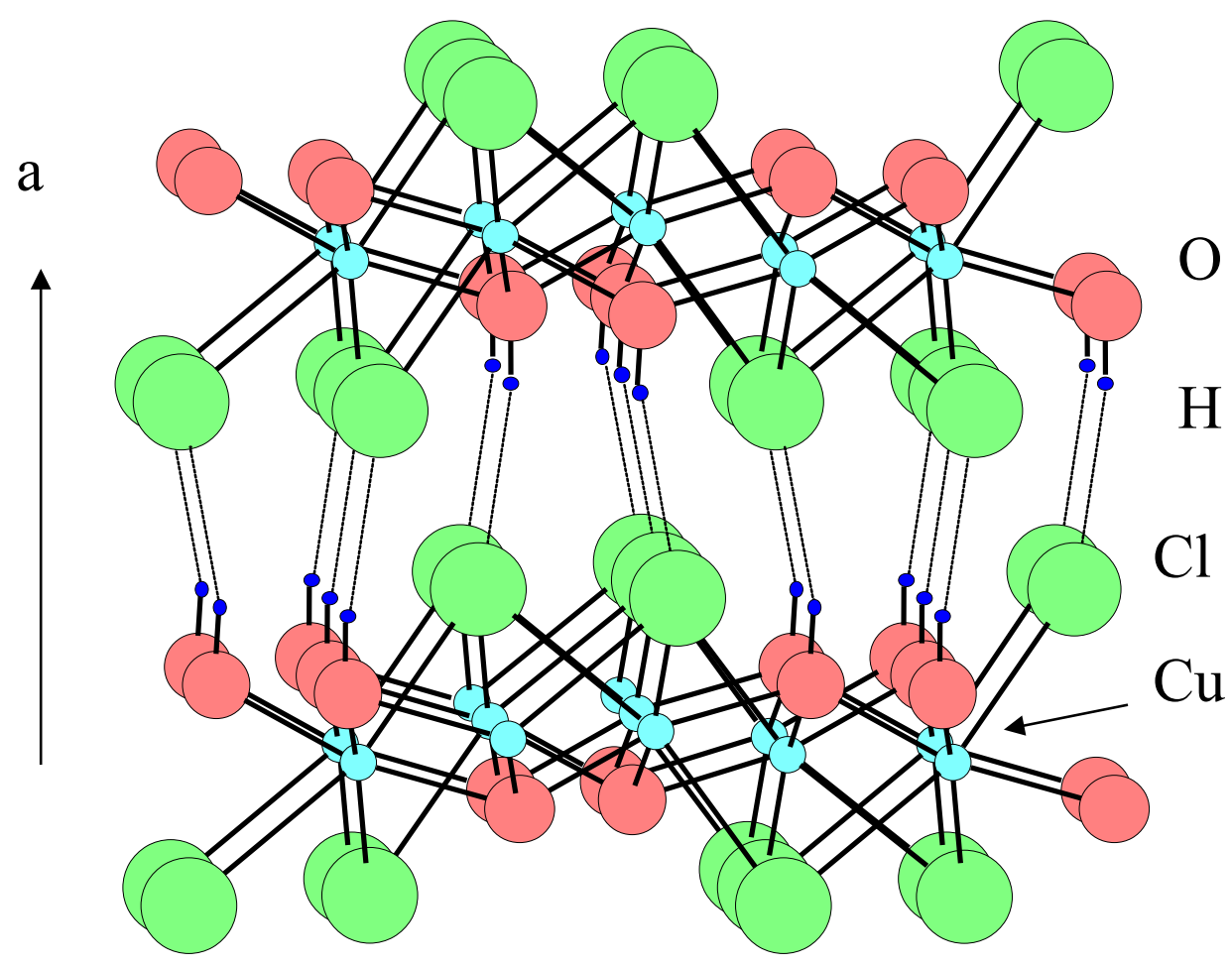



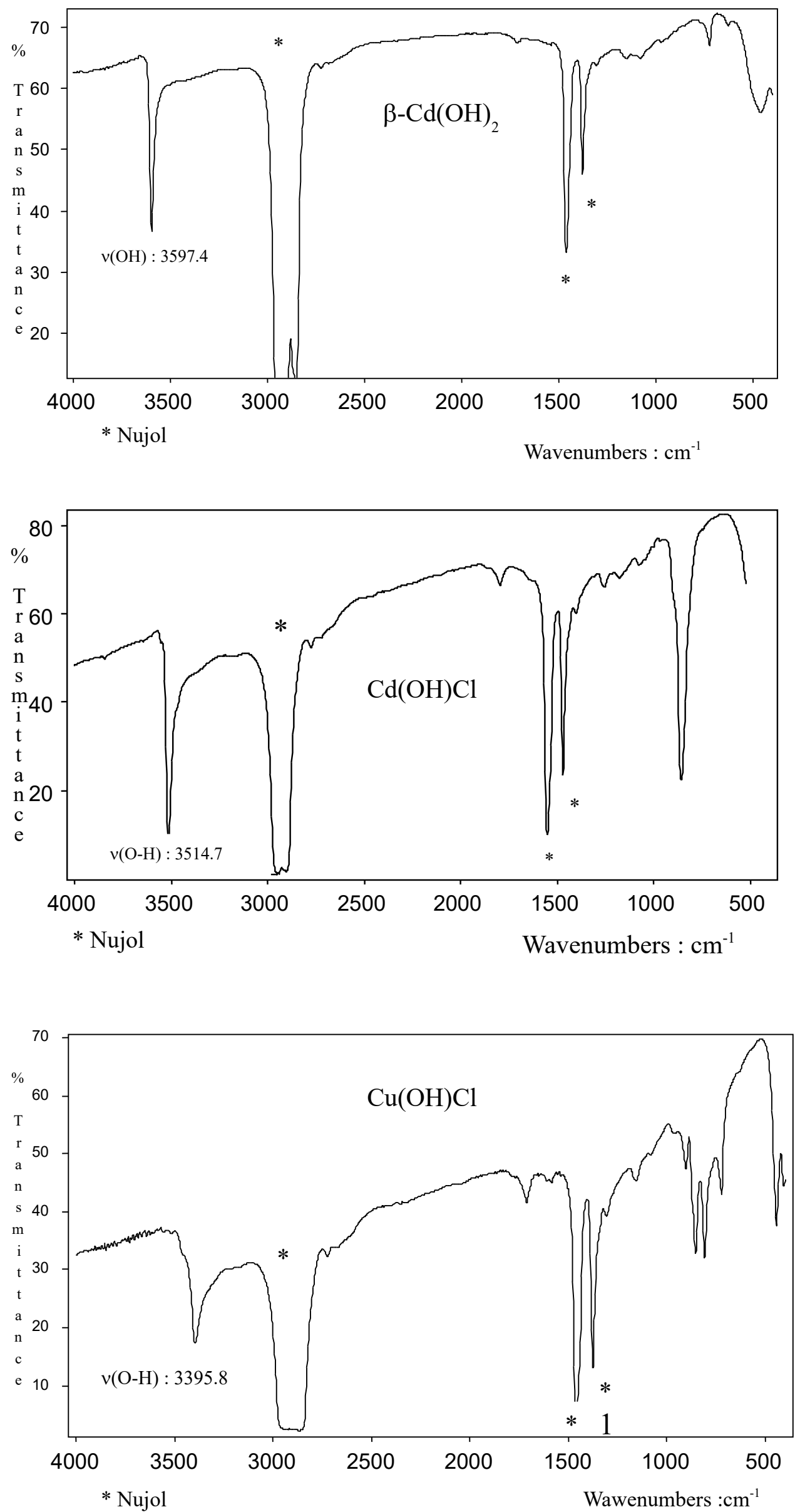
FIG. 5. IR spectra of $\beta-\mathrm{Cd}(\mathrm{OH}) 2, \mathrm{Cd}(\mathrm{OH}) \mathrm{Cl}$, and $\mathrm{Cu}(\mathrm{OH}) \mathrm{Cl}$. 